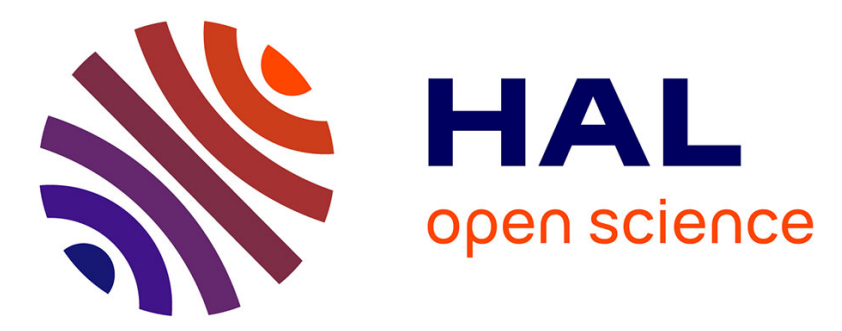

\title{
Topographic growth around the Orange River valley, southern Africa: A Cenozoic record of crustal deformation and climatic change
}

Olivier Dauteuil, Paul Bessin, François Guillocheau

\section{- To cite this version:}

Olivier Dauteuil, Paul Bessin, François Guillocheau. Topographic growth around the Orange River valley, southern Africa: A Cenozoic record of crustal deformation and climatic change. Geomorphology, 2015, 233, pp.5-19. 10.1016/j.geomorph.2014.11.017 . insu-01120228

HAL Id: insu-01120228

https://hal-insu.archives-ouvertes.fr/insu-01120228

Submitted on 25 Feb 2015

HAL is a multi-disciplinary open access archive for the deposit and dissemination of scientific research documents, whether they are published or not. The documents may come from teaching and research institutions in France or abroad, or from public or private research centers.
L'archive ouverte pluridisciplinaire HAL, est destinée au dépôt et à la diffusion de documents scientifiques de niveau recherche, publiés ou non, émanant des établissements d'enseignement et de recherche français ou étrangers, des laboratoires publics ou privés. 


\title{
Topographic growth around the Orange River valley,
} southern Africa: a Cenozoic record of crustal deformation and climatic change

\author{
Olivier Dauteuil*, Paul Bessin, François Guillocheau
}

Geosciences-Rennes, UMR-CNRS 6118 University of Rennes 1, UEB, 35042 Rennes cedex, France

*corresponding author: Olivier.dauteuil@univ-rennes1.fr, Tel: 0033223236968

\begin{abstract}
We reconstruct the history of topographic growth in southern Africa on both sides of the Orange River valley from an integrated analysis of erosion surfaces, crustal deformation and climate change. First, we propose an inventory of erosion surfaces observed in the study area and classify them according to their most likely formative process, i.e. chemical weathering or mechanical erosion. Among the various land units observed we define a new class of landform: the pedivalley, which corresponds to a wide valley with a flat erosional floor. In the Orange River valley, we mapped three low-relief erosion surfaces, each bevelling a variety of lithologies. The oldest and most elevated is (1) a stripped etchplain evolving laterally into (2) a stepped pediplain bearing residual inselbergs; (3) a younger pediplain later formed in response to a more recent event of crustal deformation. These are all Cenozoic landforms: the etchplain is associated with a late Paleocene to middle Eocene weathering event, and the two pediplains are older than the middle Miocene alluvial terraces of the Orange River. Landscape evolution was first driven by slow uplift (10 m/Ma), followed by a second interval of uplift involving a cumulative magnitude of at least $200 \mathrm{~m}$. This event shaped the transition between the two pediplains and modified the drainage pattern. A final phase of uplift (magnitude: 60 m) occurred after the Middle Miocene and drove the incision of the lower terraces of the Orange River. Climate exerted a major control over the denudation process, and involved very humid conditions responsible for lateritic weathering, followed by more
\end{abstract}


arid conditions, which promoted the formation of pedivalleys. Collectively, these produce pediplains.

Keywords: Planation surfaces, etchplain, pediplain, pedivalley, uplift

\section{Introduction}

The relief of the Earth can be analyzed from the perspective of topographic wavelength: mountains and rift shoulders correspond to several tens to hundreds of kilometres, whereas elevated intraplate landforms (high plateaus) and large depressions or "basins" extend over several thousands of kilometres. These "plateaus" are widespread all around the world and are key areas for understanding large-scale deformations associated with mantle dynamics or other lithospheric deformation processes (shear stress at the base of the lithosphere, mantle delamination, etc.) (Braun, 2010). Plateaus are a major component of African topography, and the southern African plateau, which extends from South Africa to southern Congo, is a large specimen among this population of large plateaus (Fig. 1). This vast land surface, with a mean elevation ranging from 1 to 2 kilometres, was extensively studied during the second half of the 20th century, particularly in the classic texts of King (1951; 1962) and Partridge and Maud (1987). However, little attention has since been paid to this region by geomorphologists despite the fact that it may record interactions between mantle dynamics and climate. The origin of the anomalously high elevation of the plateau and the timing of the uplift has been largely debated using landforms (mainly erosion surfaces) as markers. The characterisation of uplift has been a subject of controversy among thermochronologists measuring denudation rates throughout the Mesozoic and Cenozoic (Gallagher and Brown, 1999a, 1999b; Brown et al., 2000; Tinker et al., 2008a). Thermochronologists disagree over certain assumptions made by some geomorphologists, particularly by Partridge and Maud (1987) according to whom a planation surface is horizontal and should form close to sea level, and over related inferences about the young age of plateau uplift (typically late Oligocene to Pliocene). Thermochronological research has instead emphasized crustal uplift during the 
Cretaceous (Gallagher and Brown, 1999a, 1999b; Tinker et al., 2008a, 2008b) followed by very low Cenozoic and modern rates of denudation - e.g. less than 4m/Ma (Decker et al., 2013 and references therein). The processes causing the uplift have remained speculative: Decker et al. (2013) suggested isostatic adjustment to denudation, while Brown et al. (2002), Kounov et al. (2009) and Raab et al. (2002) advocated active tectonics. Burke and Gunnell (2008) proposed a long-term landscape evolution scenario involving successive tectonic cycles; the latest stage started $\sim 30 \mathrm{Ma}$ ago and promoted the uplift of an African Surface. This surface formed closer to sea level than assumed by authors who advocate that southern Africa has remained an elevated highland since the Mesozoic. In the northern part on Namibia, McGregor (2009) and Dauteuil et al. (2013) proposed that the land surface since the end of Atlantic rifting had remained elevated.

The main objective of this study is to analyse the evolution of the southern African plateau by tracking the uplift record of one of its subregions. The plateau landscape is analysed as an assemblage of distinct components, namely different categories of erosion surface, pediments and incised fluvial valleys. This analysis points out the importance of pediments in terms of their total surface area, and thus in terms of the dominant landscape-shaping process. We discuss (1) their relative age and link the inferred denudation chronology with (2) the timing of the uplift and the growth of relief in southern Africa. We focus our analysis on the southern border of the southern African Plateau, in an area straddling the Orange River (Fig. 1) and extending from the Great Karasberg Plateau (southern Namibia) to Namaqualand (north-western South Africa), and from the Atlantic Ocean to the Augrabies Falls.

\section{Geological evolution of southern Africa}

\subsection{Geological setting}

The continental crust of southern Africa consists of Archean cratons, surrounded by accreted Proterozoic terranes. From Carboniferous to early Permian times, the ice sheet present during the Gondwana Glaciation reshaped the landform generating a surface fossilized by the Karoo sediments (late Carboniferous to early Jurassic), most of which were supplied by the growth of a mountain belt to the south, the Cape Fold Belt 
(Johnson et al., 2006). After eruption of the Karoo flood basalts (early Jurassic: Jourdan et al., 2008), rifting occurred on both sides of South Africa. In the South Atlantic to the west, oceanic accretion first occurred during the early Cretaceous (Hauterivian: Moulin et al., 2010).

The study area is underlain by Proterozoic basement, unconformably overlain by flat-lying sedimentary rocks of Neoproterozoic (Nama Group) and Carboniferous to Permian (Karoo group) age. The Proterozoic metamorphic to igneous rocks result from the accretion of four terranes during the Namaqua orogeny (1.2-1 Ga; Cornell et al., 2006) and of the Gariep unit (on the Atlantic side) during the Pan-African orogeny (late Neoproterozoic: Gresse et al., 2006). The mainly siliciclastic Nama and Karoo sediments are preserved in Namibia. The main sedimentary accumulation is the Karoo Karasburg Basin.

\subsection{Geomorphological setting}

The southern African (or Kalahari) Plateau has a mean elevation between 1,000 and 1,400 m. A varyingly steep marginal bulge, locally reaching elevations of 2,500 m, forms the western margin of this plateau. From west to east, this marginal bulge is composed of (1) a narrow coastal plain, (2) a convex domain with inselbergs reaching elevations of 500-750 m upstream, (3) the so-called main scarp (200-400 m) and then (4) the Plateau. One major trunk river, the Orange River, cuts through the plateau with two main tributaries: the Fish River and the Voal River.

King (1956) defined three main surfaces in South Africa and later extrapolated them to the whole of Africa (King, 1963): the Gondwana Surface was considered to be of Jurassic age, the African Surface of late Cretaceous to "early Tertiary" (Eocene) age and the Post-African Surface of "late Tertiary" age. Based on these observations, King (1955) defined the concept of a pediplain, with a model of topographic growth tied to a model of passive-margin scarp retreat (see discussion below). The staircase of planation surfaces, instead of the scarp retreat model, subsequently became very popular in southern Africa. King's successors (e.g. Partridge and Maud, 1997) mainly focused on the plateau uplift component, suggesting a very recent, late Pliocene, age of uplift. Burke and Gunnell (2008) confirmed a post-Oligocene age for the uplift as previously suggested by King, but tied it to the mantle-related "swell" dynamics of the African 
continent, which appear to have promoted large-scale plateau uplift. Although the timing of uplift advocated by Burke and Gunnell (2008) does not contradict existing thermochronological results, which indicate rapid denudation in response to rifting during the late Cretaceous (e.g. Gallagher and Brown, 1999a, 1999b; Brown et al., 2000), it introduced the notion of a second cycle of landscape-changing crustal buoyancy during the Cenozoic. This event was not detected by apatite fission-track analysis, possibly because it did not trigger a geomorphological response involving deep denudation (i.e. no rock-cooling signal).

Using a different angle of approach to Burke and Gunnell (2008), here we focus on the meaning of landscape signatures provided by assemblages of erosion surfaces, valleys and hillslopes on both sides of the Orange River within $400 \mathrm{~km}$ of its mouth (Figs. 3 and 4). To the north, the Kalahari Plateau is filled with Kalahari sands dated as late Miocene in the Makgadikgadi Pan (Botswana) (du Plessis, 1993). Mac Farlane et al. (2010) described a lateritic weathering profile attributed to the African Surface, generally dated as flat and low-lying between $\sim 100 \mathrm{Ma}$ and $\sim 34 \mathrm{Ma}$. To the south, the southern African Plateau in the Bushmanland area is scarred by a network of weakly preserved anabranching river channels of middle Miocene age (de Wit and Bamford, 1993).

Pediments have long been recognized between the Orange River and Namaqualand (Mabbutt, 1955). It is not entirely clear how these pediments relate chronologically to the two fluvial terrace levels described by van Wyk and Pienaar (1986) in the lower reaches of the Orange River, but the upper terrace has yielded Burdigalian ( $\sim 21 \mathrm{Ma}$ to $\sim 16 \mathrm{Ma}$ ) flora (Pickford and Senut, 2003).

\subsection{Climatic setting}

During Mesozoic to Cenozoic times, the climate underwent large variations with major impacts on landscape evolution in southern Africa. Burke and Gunnell (2008) summarised this evolution at the scale of the African continent. Knowledge about palaeoprecipitation is mostly based on palaeobotanical evidences. The Cretaceous was characterised by two sharp transitions: semi-arid to arid around $130 \mathrm{Ma}$ (Hauterivian) and $85 \mathrm{Ma}$ (Santonian), with progressive aridification between 130 and $85 \mathrm{Ma}$ (Gomez 
et al., 2002; Sandersen, 2006). The second half of the late Cretaceous up until the middle Eocene (i.e. 85-40 Ma) was very humid along the Atlantic coast (de Villers, 1999; Sandersen, 2006) but no data are directly available for the Paleocene. This humid period was coeval with the formation of laterite in Namibia (Pickford and Senut, 1999), a widespread process across Africa with well constrained age brackets for West Africa between 59 and $45 \mathrm{Ma}$ (Beauvais et al., 2008). No data are available for the Oligocene, i.e. the early stages of the "icehouse" period. The early Miocene (Aquitanian) was humid (Bramford and de Wit, 1993; Bramford, 2000). After the middle Miocene, the coastal area of SW Africa became and remained arid (Pickford and Senut, 1999).

\subsection{Study area}

We studied both sides of the Orange River valley from $26^{\circ} 50^{\prime} \mathrm{S}$ to $30^{\circ} 10^{\prime} \mathrm{S}$ and from the shoreline eastward to $21^{\circ} 15^{\prime} \mathrm{E}$. The area was large enough to allow us to work out how the lower reaches of the Orange River, one of the largest fluvial systems in southern Africa, evolved below the Augrabies Falls. The Orange River valley marks a main boundary between a rather flat domain to the north and a dissected domain to the south (Fig. 1). The inner plateau displays a smooth topography at an elevation of $\sim 1,000$ $\mathrm{m}$, with some mountain ranges reaching 2,200 $\mathrm{m}$. The vast, low relief area displays undulations with amplitudes that increase towards the Orange River and can be subdivided into discrete, diagnostic land units described later. In the northwest, the plateau exhibits a number of elevated topographic ranges striking NE-SW and separated by a corridor. These ranges are bounded by normal faults that have generated either tilted blocks or horsts and grabens, as in the Fish River Canyon (Mvondo et al., 2011). The marginal topographic bulge to the west stands at an elevation of approximately $1,200 \mathrm{~m}$. It is deeply incised by the Orange River and by other coastal rivers that have been progressively cutting back into the plateau edge. The coastal zone extends from base of the marginal bulge to the coast. The connection with the marginal bulge is progressive in the wider segment and, contrary to common belief, it does not systematically for a scarp.

\section{Erosion surfaces: terminology used}


Erosion surfaces are diagnostic landforms, mainly at the scale of a continent such as Africa. The nature, terminology and origin of erosion surfaces since the definition of the peneplain and the geographical cycle by Davis (1899) have been a subject of debate (e.g. Migon, 2004a; Twidale, 1983a, 1983b; Phillips, 2002). In this study, we propose an inventory of erosion surfaces of different types that occur along the Orange River valley and its surrounding plateaus. We also distinguish landforms according to their surface area.

\subsection{Large-scale $\left(>10^{4} \mathrm{~km}^{2}\right)$ erosion surfaces}

An erosion, or planation, surface (Migon, 2004a) is a nearly flat land surface that cuts across underlying structures and rock outcrops. It may be incised by the drainage network and display isolated, residual hills. Such surfaces are often warped, most of the time by long wavelength deformation (x100 km). They can later undergo reworking (1) by other planation processes (see discussion below), in this case becoming polygenetic erosion surfaces; or (2) by river or pediment incision in response to a base-level fall. In that case, the erosion surface becomes degraded or dissected. Because our investigative method of long-term landscape development is highly sensitive to the definition and interpretation of land system features, below we list the four diagnostic types of erosion surface detected in the study area (Fig. 2):

(1) Peneplain. This word, defined by Davis (1899), has several definitions and origins (discussed in Migon, 2004b). It was originally defined as "a nearly featureless plain" with "perceptible inequalities, amounting frequently to two or three hundred feet" and connected to the base level, i.e. the sea. No idea of processes was provided. Later (Davis, 1930; Holmes, 1955), peneplains were assumed to be fluvial erosional surfaces formed by the downwearing of hillslopes that progressively flatten the relief. Even though some researchers question the occurrence of true peneplains (e.g. Phillips, 2002), here we retain the definition of a fluvially-shaped surface.

(2) Pediplain. The pediplain was defined by King (1953) in contradiction to the peneplain, as an erosion surface resulting from the parallel retreat (backwearing) of scarps (hillslopes) and composed of many coalescent pediments (see definition of these elementary landforms in section 3.2). Mabbutt (1996) proposed that pediments resulted from processes of sheet flow involving alternate cycles of 
shallow burial by lag deposits and subsequent stripping. The processes that drive the formation of a pediplain are widely debated and range from climate to crustal deformation. Wirthmann (1999) has well summarised the evolution of these concepts.

(3) Mantled etchplain. This variety of land surface is typified by the presence of a weathering mantle, often lateritic in nature, and often capped by iron-rich duricrust (Mabbutt, 1966; Millot, 1980; Grandin and Thiry, 1983). The term etchplain has received broad definitions (see Thomas, 1989a), elaborating on the early intuitions of Wayland (1933). The consensus is that an etchplain is a surface of bedrock corrosion resulting from chemical weathering (i.e. etching) and physical processes. The indurated surfaces are often topographically inverted and form mesas, i.e. isolated plateaus (Chardon et al., 2006). Mantled etchplains (Migon, 2004c) produced by chemical weathering can undergo degradation by partial stripping of the weathering mantle. Exposure of the weathering front develops a partially stripped etchplain (see below) but the capacity of chemical weathering to level a rock surface is still being discussed. The maximum thickness of the lateritic profile is often tens of metres (Bardossy and Aleva, 1990) and known to reach maxima of $\sim 100 \mathrm{~m}$ (Beauvais and Chardon, 2013).

(4) Stripped etchplain. Stripped etchplains correspond either to the exposed base of the weathering profile, or weathering front (Mabbutt, 1961), or to a surface with vestiges of weathering profiles dissected by incised rivers or pediments (Twidale and Bourne, 2013) with possible vestiges of deep weathering profile (laterites) on some hillslopes (Büdel, 1957; Thomas, 1989a, 1989b). In this second type of stripped etchplain, a major question is the kinematics of the incision, with two plausible scenarios in response to base-level fall: (1) continuous chemical weathering and physical stripping controlled by a seasonal regime (Büdel, 1957, 1982; Bremer, 1993); or (2) alternations of chemical and mechanical erosion dictated by periodic climate change (Thomas, 1989a, 1989b; Millot, 1981; Beauvais et al., 2008).

\subsection{Elementary erosion surfaces: pediment, inselberg, pedivalley}


The literature has long distinguished between pediments and wash pediments, or glacis, but below we also introduce a landform previously described but never given much prominence in the literature: the pedivalley.

Pediments are gently inclined, low-relief erosional surfaces truncating the underlying rocks. They display concave or straight longitudinal profiles and are mantled at most by thin and discontinuous sediment layers (Whitaker, 1979; White, 2004; Dohrenwend and Parsons, 2009). Since Davis (1938), who opposed sheetflood and streamflood as two likely candidates in the formation of pediments, the processes driving pediment evolution have continued to be debated. Running water should (1) cover the pediment entirely (no channel incision) and (2) its transport capacity should ensure evacuation of the eroded debris. At times of intense flooding, the flow is a dense mixture of water and sediments (sheetfloods), and is more efficient if a large amount of soft rocks is available upstream (e.g. saprolite in the case of a weathered basement).

Two types of pediment have been defined based on their present-day climatic distribution: arid and tropical pediments. Mammericks (1964), who compared pediments in Congo and the American West, suggests a difference in size between the two types: dryland pediments were steeper and smaller $\left(0.5-11^{\circ}\right.$ and 1 to $600 \mathrm{~km}^{2}$; Salomon, 2007), with layers of coarse-grained lag deposits ( $>4 \mathrm{~mm}$ ), whereas the tropical pediments were larger, with shallower gradients and mainly clay-rich lag deposits. In the case of modern dryland pediments in Nevada, Dohrenwend and Parsons (2009) shows that the pediments are not controlled by variations in the underlying lithology. In contrast, Ollier (1959), Mabbutt (1966) and Thomas (1989a, 1989b) have indicate that tropical pediments were narrowly controlled by the thickness of the underlying lateritic profiles, and that lithology was another control variable. Dohrenwend and Parsons (2009) also showed that both downwearing and backwearing processes occurred on pediments.

Glacis (Dresch, 1947) are soft-rock pediments (typically in shale, etc.), with a concave-up longitudinal profile ( 1 to $12^{\circ}$ ) dominated upstream by steep slopes and often mantled by a large thickness of debris. The main differences with rock pediments are (1) the presence of sediments, which indicates short transport distances from the source and periods of sheetwash, and (2) their ubiquitous location regardless of climatic context. 
Here, we define a new term to characterise pediments that look like wide valleys with flat erosional floors. This type of landform, which is characteristic of the study area, has already been described in the literature (e.g. Mammericks, 1964, Thomas, 1989a; Thomas, 1989b) but not named. We tentatively call them pedivalleys. The planation process results from the parallel retreat of a pre-existing scarp in combination with bedrock weathering.

Inselbergs are isolated hills that stand above the surrounding, flatter erosional plain. This term was restricted to dome-shaped landforms in metamorphic and plutonic rocks. Inselbergs record topographic lowering due to base-level fall. They are relict features of weathering periods (e.g. Thomas, 1978; Twidale, 1983a; Migon, 2006), and shaping by other processes such as wind has also been considered (e.g. Selby, 1982). Whatever the process, the bedrock undergoes very low rates of erosion (1-2 m/Ma in Namibia, Matmon et al. (2013)). King (1951) suggested that inselbergs were pediplanation residuals. Inselbergs are shaped in two stages: (1) a weathering period in an environment corresponding to a mantled etchplain, with a topographically irregular weathering front (typically controlled by lithology); followed by (2) a fall in base level and a denudational response that removes at least the softer weathered rock across expanding pediment surfaces. This results in a stripped etchplain. Tropical inselbergs thus result from the exhumation of areas with a thin lateritic profile. The height of the inselbergs can attain hundreds of metres, i.e. more than observed weathered thickness maxima $(\sim 100 \mathrm{~m})$. Thus, high inselbergs result from the downward migration of the weathering front and consequently indicate a continuously falling base level. The presence of inselbergs implies that a surface corresponding the top of laterite profile existed at a greater elevation than the present-day inselberg summits. That surface was likely a mantled etchplain.

\subsection{Methodology and data}

Geomorphological analysis was carried out by mapping the assemblage of erosion surfaces detected in the study area in order to hypothesize the succession of events and processes most likely to explain the landscape evolution. The mapping was performed by combining (1) field observations, (2) DEM analysis using SRTM data processed with the ArcGISC suite, and (3) Google Earth interpretations. Discrimination 
between the different erosion surface categories was performed using criteria such as landform shape, spatial extent and continuity, and the nature of changes in hillslope and scarp morphology. Absolute elevation and flatness were not among the critical criteria because a surface may acquire a proportion of its gradient from tectonic or epeirogenic deformation. One potentially useful diagnostic difference for distinguishing between planation processes is the drainage pattern. We extracted the drainage network using ArcGISC processing routines. Despite the rather flat topography, the extracted drainage network displays a consistent pattern with variations confirmed both in the field and by remote sensing data. A detailed analysis was performed on the Gamkab Valley, a key area for understanding the relationships between the erosion surfaces and their driving processes.

Based on the mapping, we distinguished three erosion surfaces (Fig. 3): an etchplain, an intermediate pediplain (pediplain 1), and a lower pediplain (pediplain 2). Preserved and dissected surfaces were mapped, allowing for an interpolation and then a $2.5 \mathrm{D}$ reconstruction of the shape of these landforms. The drainage network was reported on the surfaces. The map produced is interpreted in terms of climate changes and vertical deformation, and an absolute time frame is proposed by correlation with evidence provided by the regional literature.

\section{Geomorphic analysis of the Orange River valley between the Augrabies Falls} and the sea

\subsection{The upper etchplain}

Depending on the underlying lithology, this surface can occur (1) on slightly tilted sedimentary rocks, nearly flat and varyingly degraded; or (2) on crystalline basement (gneiss, granite), more undulating with some flat areas, and partly degraded around the edges (Fig. 3). In its degraded portions, the lower surface (pediplain 1, see below) carries inselbergs that never rise above the horizontal projection of this upper etchplain. Weathering products, mainly kaolin (i.e. base of the lateritic weathering profile), are preserved both on hillslopes with undulating surfaces and on inselbergs. The residual inselbergs and residual lateritic profiles prove that a thick and more extensive laterite profile previously existed. The corresponding land surface was higher than the summits 
of the peripheral inselbergs and was at least at the same elevation as the high etchplain. No complete laterite profiles are preserved in the study area (no evidence of iron-rich duricrust, even on the well-preserved flat surface). This means that this surface is more or less the base of a stripped weathering profile. This etchplain is preserved as a plateau and occurs in the north-west of the study area (Karasburg plateau). The ranges, bounded by faults, correspond to tilted blocks that are younger than the erosion surfaces. South along the Orange River or in the Springbok area, this surface is degraded and preserved as clusters of hills (inselberg fields with some flat tops)

\subsection{Pediplain 1}

Pediplain 1 (Figs. 3, 4) corresponds to a continuous assemblage of elongated pedivalleys limited by low-angle longitudinal breaks in slope. The pedivalleys are up to $40 \mathrm{~km}$ wide and up to $100 \mathrm{~km}$ long, with an upslope-downslope difference in elevation of a few tens of metres and a mean longitudinal slope up to 1\% (Fig. 4). A veneer of scattered quartz-gravel accumulations covers them. Some (rare) occurrences of kaolinitic saprolite crop out on the pedivalley surfaces themselves or at the base of the upstanding scarps or inselbergs. The co-presence of remnants of the stripped lateritic profile and of inselbergs suggests that this pediplain results from the transformation of the stripped etchplain (upper etchplain) defined above. The topographic boundary between pediplain 1 and the upper etchplain is either a scarp (up to $160 \mathrm{~m}$ high) or a more discrete break in slope (Fig. 4).

Pediplain 1 (Figs. 3,4) extends from the scarp that forms the boundary with the high etchplain in the north, to the Orange River in the south. It displays slight changes in regional slope on both sides of longitude 19³0': in the west the regional slope is to the west and in the east, to the east. This surface is degraded close to the Orange River, where the pediplain is preserved in the form of dissected flat-topped hills (mostly inselbergs). The Orange River has deeply incised this surface where it crosses the marginal bulge (up to $400 \mathrm{~m}$ of incision). The reconstructed shape of this surface (including the flat-topped hills close to the Orange River valley) defines a smooth convex envelope surface toward the Orange valley.

\subsection{Pediplain 2}


Pediplain 2 is the lowest surface and grades directly to the Orange River in several places (Fig. 3). This surface corresponds to coalescent pedivalleys that are smaller and less elongated than those of pediplain 1: it is $60 \mathrm{~km}$ long, $30 \mathrm{~km}$ wide and has a mean DEM-derived slope of up to 3\%. Scarce thin alluvial deposits are preserved on the pediments. No occurrence of kaolinitic saprolite was found: this is no longer a stripped etchplain. It is easy to distinguish this pediplain from pediplain 1 close to the Orange River valley because this surface is lower in altitude by tens of metres. However, telling the two apart is more difficult upstream because pediplains 1 and 2 sometimes merge and are only separated by a low-angle break in slope. Pediplain 2 extends for approximately $50 \mathrm{~km}$ on both sides of the river. The Augrabies Falls correspond to the upstream break-in-slope of this pediplain (Fig. 4). The present-day rivers (mainly the Orange River) have not significantly incised this surface, indicating that the present-day Orange River has been acting as the local base level of pediplain 2 . The profile of pediplain 2 has upstream from convex- to concave-up. Pediplain has overprinted the older pediplain (pediplain 1), and the relationship is well expressed in the Gamkab pedivalley.

\subsection{Growth of pediments 1 and 2: the Gamkab pedivalley}

The Gamkab pedivalley (Fig. 5) has a sub-rectangular shape striking NE-SW, is $142 \mathrm{~km}$ long and $40 \mathrm{~km}$ wide, i.e. an area greater than 5,600 $\mathrm{km}^{2}$. The elevation ranges from $1,430 \mathrm{~m}$ (NE) to $340 \mathrm{~m}$ (SW), i.e. an average slope of $0.7 \%$. This valley is divided into two longitudinal segments: upstream where it belongs to pediplain 1, and downstream to pediplain 2. The separation between these two segments corresponds to a break in slope (Fig. 5) associated with an increase in slope downstream of up to $2 \%$.

In the upper part (pediplain 1), the NW flank displays drainage with a widespread braided pattern that evolves into a parallel pattern close to the main outlet of the Gamkab catchment. This change fits with the downward increase in slope. The widespread braided pattern covers a huge area and was associated with a thin layer of gravel indicating that it resulted from the action of running water with low transport capacity. In the lower part (pediplain 2), the drainage is more dendritic. At the boundary between the two pediplains, dendritic streams invade the upper parts and capture some 
braided streams. The river profile displays a convex shape in the upper part and a linearto-concave shape in the lower part. This change in profile shape coincides with the change in drainage pattern and implies that the upper and lower parts were shaped by different processes. The morphology of the Gamkab valley has thus recorded two denudational events. The first generated a convex shape and involved fluvial or hillwash processes water. During the second period, denudation was comparatively more efficient: the valley slopes steepened and the drainage pattern became dendritic and incised the pre-existing surface.

\subsection{Drainage network on the pediplains}

The drainage network automatically extracted from the DEM (Fig. 6) displays a network with two patterns: a braided to parallel pattern and a more or less dendritic pattern. Meanders only affect the Fish River and the Konkiep River. The first type prevails on pediplain 1. The braided to parallel streams join a perpendicular trunk stream, well illustrated in the upper part of the Gamkab valley. The trunk streams flow eastward. The sub-dendritic pattern occurs on pediplain 2, with its main streams connected to the Orange River. These main streams trend N-S. The two pediplains are thus associated with contrasting drainage patterns, showing that hydrological conditions changed between the two stages.

We analysed the longitudinal profiles of 49 rivers in the area (Fig. 7). The profiles were automatically extracted from the DEM with the ArcGISC software. To compare profile shapes, length and elevation range were normalised to 1 . This kind of graph highlights three types of river profile: linear, convex-up, and concave-up. Figure 7 illustrates the spatial distribution of these three patterns. The convex shape largely dominates the region (approximately $3 / 4$ ), mainly inland; the concave shape represents less than $1 / 4$ of the total, and the linear pattern is poorly represented. The concave rivers are mainly present in the coastal belt and surrounding areas. The convex rivers flow preferentially on the erosion surfaces and have a dendritic to parallel drainage pattern. Several rivers have a composite profile shape, such as the Orange River, which, however, mainly exhibits a convex channel profile. The profile is concave when it flows through the coastal plain and at the plateau edge, i.e. where it has steeply incised the topography. Thus the distribution of the longitudinal profiles correlates with the morphology: convex 
on the flat areas, concave in the incised areas. This points to a genetic relationship between these two kinds of channel profiles and surface morphology. The longitudinal profile of the Orange River displays one main knickpoint located at Augrabies Falls.

\section{Discussion}

This study shows that three erosion surfaces have shaped the landscape on both sides of the Orange River valley. Although the number of surfaces corresponds to the number given in previous studies (King, 1951; Partridge and Maud, 1987), their interpretation is approached from a different methodological angle and articulated with genetic processes. It is nonetheless possible to propose a correlation with these previous works: the African surface fits with the high etchplain, and pediplains 1 and 2 with the post-African surface.

\subsection{Erosion surfaces and lithology}

Before attempting to interpret the erosion surfaces in terms of climate and/or crustal deformation, we checked to see if they were controlled by lithology (Fig. 8). The maps in Figure 8 show the three surfaces classified as a function of lithology and age. The geological units are those provided by South African Geological Survey maps. Pediplains 1 and 2 are associated with all lithologies consequently are not controlled by the lithology. The high etchplain is mainly dominated by one lithology corresponding to Neo-Proterozoic sediments and to a much smaller amount of volcanic rocks. However, rock types similar to the high etchplain were encountered on both pediplains, suggesting an absence of lithological control over erosion surfaces whatever their age or position in the landscape. Structural controls, in contrast, appear to be more important than rock composition. Horizontal strata, for example, appear to be more resistant to weathering and erosion than inclined strata.

\subsection{Topographic growth and landscape evolution processes}


Here we reconstruct the successive stages of topographic growth, starting from pediplain 2, which is the best preserved and is connected to the present-day Orange River. The description is limited to west of the Augrabies Falls (Fig. 9).

Pediplain 2 is the younger large planation surface of the study area. It connects to the Orange River, which is the present-day local base level and is itself directly connected to sea level to the west of the Augrabies Falls. It does not exist over the entire study area, especially over the marginal bulge, and disappears east of Augrabies Falls. Close to Noordoewer, an alluvial terrace, the age of which has been debated, covers this pediplain (Van Wyk and Pinaard, 1986; Jacob et al., 1999). Pediplain 2 directly reworked pediplain 1 close to the Orange River, as previously described through the example of the Gamkab Valley. This overpint increased the depth of fluvial incision and the general slope steepness, and promoted drainage piracy west of the Augrabies Falls. These features indicate that the transition between the pediplains corresponds to a significant fall in base level.

Pediplain 1 is a composite surface with pediments cut into the upper etchplain. Several markers, such as inselbergs, a residual lateritic profile, and residual hills forming undulating topography testify to the presence of an ancient lateritic profile over the entire study area. A minimum thickness for the weathered basement can be estimated by adding average inselberg height (around $150 \mathrm{~m}$ ) to the weathering profile thickness $(50 \mathrm{~m})$ : from this we infer that at least $200 \mathrm{~m}$ of basement rock was weathered and selectively stripped. This did not occur during a single long period, but rather resulted from an alternation of weathering and mechanical stripping. The upper etchplain is the remaining clue to the weathering episode that preceded the development of pediplain 1 . The interpolated extent of this surface from its various vestiges indicates that the entire study area was deeply affected by weathering as far as the coast. The transition from the upper etchplain to pediplain 1 was marked by a fundamental change in dominant process: at first deep weathering, followed by mechanical erosion. This step change in geomorphological processes is ascribable to a major climatic change from humid tropical to semi-arid. To summarize, landscape evolution in the study area was successively controlled by climate change and by a falling base level.

The drainage pattern is an excellent constraint for determining the amplitude of base-level fall. On pediplain 1, the drainage network suggests water flowing as a parallel series of braided channels, all connecting to a main collector stream that followed the 
axis of the pedivalley. East of $19^{\circ} 30^{\prime} \mathrm{E}$, these main streams flowed toward the southeast and northeast, and converged toward a palaeovalley corresponding to the proto-Orange River. To the west of this longitude, the streams run westward. On pediplain 2, the drainage pattern is more dendritic, and the main streams connecting to the Orange River strike N-S after a distinct elbow of capture. This change in stream direction corresponds to a main change in the regional slope. Consequently, the base-level fall that precipitated the transition between pediplain 1 and pediplain 2 was induced by a dynamic crustal event, tectonic or otherwise, that tilted this part of the plateau westward.

\subsection{Event chronology}

Apart from the Orange River terraces, no components of this landscape have been dated. The age of the main lateritic weathering at the origin of the highly stripped etchplain can only be discussed using regional comparisons. A major period of weathering is known to have occurred in NW Africa from the Palaeocene to middle Eocene times (59-45 Ma, based on ${ }^{39} \mathrm{Ar}-{ }^{40} \mathrm{Ar}$ dating of lateritic profiles in Burkina Faso: Chardon et al., 2006; Beauvais et al., 2008). This Paleogene weathering event coincides with the age of the African Surface described by King (King, 1951). However, such longdistance correlations between local studies are difficult to fit into a fully coherent picture at the scale of the African continent (Burke and Gunnell, 2008). Thick kaolinitic saprolite is known to occur below the Kalahari sands (McFarlane et al., 2010) as well as all along the coastal plain and amidst the upstream convex relief below the escarpment (in Namibia, Pickford and Senut, 1999; in South Africa: Heckroodt, 1992; Botha, 2000). The occurrence of late Oligocene (27.4 Ma) to earliest Pliocene (5.2 Ma) weathering profiles on the South African Plateau north of Kimberley (Gutzmer et al., 2012) challenges the view that kaolinitic saprolite should be Paleogene rather Neogene. However, closer to the study area, in the Sperrgebiet area of southern Namibia, the main weathering event is dated stratigraphically to before the deltaic to aeolian Buntfeldshuh Formation, i.e. should be older than late Eocene (Pickford and Senut, 1999; Pickford et al., 2008). This would confirm the early Paleogene as the most likely time window during which deep weathering occurred across the upper etchplain. It follows that pediplains 1 and 2 are younger rather than Neogene. 
The youngest known landforms in the landscape are the fluvial terraces of the Orange River, of late early Miocene age (Pickford and Senut, 1999, 2003). Debate focuses on knowing the relationships between these dated terraces and the terrace of unknown age located upstream of the marginal bulge in the Noordoewer area (van Wyk and Pienaar, 1986; Jacob et al., 1999; de Wit, 1999): whether it is the same age or older because of its much higher elevation (at least $100 \mathrm{~m}$ ) remains unresolved. Regardless of how this is interpreted, pediplains 1 and 2 are older than the late early Miocene (Burdigalian, 20-15 Ma).

\subsection{Magnitude of vertical displacements}

The study area is located inland from the complex transition zone that separates the highlands from the sea. We determined the relative vertical displacement by analysing the change in local base level. Close to sea level, base-level variations can be either eustatic or tectonic. Because the longitudinal profile of the Orange River suggests equilibrium west of the Augrabies Falls, with no major knickpoints between the Falls and the coast (Fig. 7), we assumed a homogeneous behaviour of the geomorphic system in the coastal belt. The $60 \mathrm{~m}$ incision in the lower Orange terraces (Van Wyk and Pienaar, 1986) can thus be attributed to eustatic changes. The amplitude of sea-level variations has been greatly discussed since the classic works of Haq et al. (1997), who suggested a sea-level fall of 210-260 m since the middle Eocene. Miller et al. (2005), and more recently Rowley (2013), have suggested much lower values. Miller et al. (2005) suggested values between 40 and $120 \mathrm{~m}$ (but no more than $40 \mathrm{~m}$ since the late Eocene) and Rowley (2013) suggest values no greater than $20 \mathrm{~m}$ since $40 \mathrm{Ma}$. These recent data may indicate that the maximum sea-level fall since the end of the weathering period is less than $50 \mathrm{~m}$. This suggests that most of the base-level fall recorded by pediplains 1 and 2 should be ascribed to uplift of the continent crust.

Three kinds of deformation controlled topographic growth (Fig. 9). Slow uplift during the Paleocene weathering stage (upper etchplain) reached a magnitude of at least $250 \mathrm{~m}$. This minimal value is constrained by the elevation of the inselbergs. The uplift rate can only roughly be determined because of high uncertainties on the ages, and stands around 10m/Ma. The faster and shorter uplift event that initiated the overprint of pediplain 1 over pediplain 2 generated these two nested pediplains and 
promoted valley incision close to the marginal bulge. Based on the depth of the incised valleys, this uplift is estimated to be at least $200 \mathrm{~m}$. The third and final deformation event was recorded by the drainage pattern: the dominant flow direction changed from east to west. This change demonstrates a reversal in the regional slope caused by a westward tilt of the regional topography. Overall, total uplift has reached at least $450 \mathrm{~m}$ since the Early Paleocene.

This Cenozoic uplift at the origin of the present-day plateau does not rule out the evidence provided by thermochronological data, which indicates a major denudation and then possible uplift during late Cretaceous times (Gallagher and Brown, 1999a, 1999b; Tinker et al., 2008a, 1999b). The measurement of silicilastic sedimentary fluxes along the Atlantic passive margin (Guillocheau et al., 2012) indicates an amount of silicilastic sediments of around 2 millions of $\mathrm{km}^{3}$, most of it sourced by onshore denudation. As previously argued by Burke and Gunnell (2008), this means that the first late Cretaceous plateau was removed by denudation and that the present-day relief is Cenozoic in age and probably preserved because of persistently arid environments in this region since the middle Miocene.

This work highlights how the detailed mapping of erosion surfaces and their genetic interpretation in terms of process provides significant constraints on local variations in base level. Geomorphic proxies that should be researched in the future include: (1) etchplains with tall inselbergs, (2) staircases of pediplains and their associated incised valleys, and (3) changes in drainage pattern. At localities close to the coast, the variations in base level were higher than the eustatic variations during the studied time interval; these variations were therefore caused by vertical crustal displacement.

\section{Conclusions}

The aim of this paper was to describe and interpret landscape evolution on both sides of the Orange River downstream of the Augrabies Falls. We proposed a model of landscape growth for the southern African Plateau, on both sides of the Orange River valley. Our analysis focused on erosion surfaces and inselbergs, in order to discriminate between landscape changes caused by climate and landscape changes caused by crustal movement. 
The main landform assemblages are etchplains and pediplains associated with incised valleys. This confirms the results of earlier work (Mabbutt, 1955, 1966; King, 1951, 1955; Burke and Gunnell, 2008). We clarified the nomenclature of erosion surfaces using a process-based approach (i.e. chemical weathering-dominated vs. mechanical erosion-dominated), identifying three main types among a theoretical range of four: peneplain, pediplain, mantled etchplain and stripped etchplain. We also described the widespread occurrence of a class of landform under-reported until now, the pedivalley, which corresponds to a broad pediment forming an unusally wide valley. Populations of coalescing pedivalleys form pediplains.

Three stepped land systems were defined, from oldest to youngest and from top to bottom: (1) a stripped upper etchplain (exhumation of the base of a lateritic profile); (2) an upper pediplain (pediplain 1) bearing isolated inselbergs (these locate the high points of the upper etchplain weathering front); (3) a lower pediplain (pediplain 2), which connects to the present-day Orange River.

All these erosional surfaces are Cenozoic in age, starting with the major African-scale weathering event of late Paleocene to middle Eocene age (60-45 Ma) and ending in the late early to early-middle Miocene (20-13 Ma) (age provided by the Orange River alluvial deposits on pediplain 2).

The studied landforms record an uplift of the southern African Plateau during Cenozoic times in two stages: (1) slow uplift (10m/Ma) during an interval that started at the end of the major weathering period (formation of the upper etchplain during the middle Miocene) and ended after the onset of a lasting shift to drier conditions (formation of pediplain 1). This changed the emphasis from chemical weathering to physical erosion. (2) a second stage of uplift, to which the landscape responded by nesting pediplain 2 into pediplain 1 . This promoted an increase in regional slope and a substantial reorganisation of the drainage pattern (watershed, stream direction, channel style, etc.). A semi-quantitative estimate of the uplift can be provided from the height of the tallest inselbergs (around $250 \mathrm{~m}$ of vertical movement for the first uplift) from the depth of incision by rivers displaying equilibrium profiles (minimum of $200 \mathrm{~m}$ of vertical movement for the second uplift interval) Neither of these uplift magnitudes created a denudational response of sufficient magnitude to be detected by apatite fission-track dating methods, which explains why this Cenozoic history of uplift and landscape change previously evaded detection by thermochronological methods (Burke and 
Gunnell, 2008). The latter only captured the major peak of syn- and early post-rift denudation during the Mesozoic.

Climate was a major control over erosional processes. Periods of the Cenozoic dominated by high precipitation and little or no uplift were characterised by intense weathering and the formation of deep lateritic profiles. During more arid conditions, mechanical denudation prevailed at rather low rates and promoted the formation of pediments, which achieve spectacular topographic smoothing of bedrock surfaces but shallow denudation. In agreement with Burke and Gunnell (2008), this lasting aridity probably explains why more than 15 Ma after the last pulse of uplift, the elevated plateau is still there.

\section{Acknowledgments}

ANR TOPOAfrica and CNRS-INSU project Action Marges funded this work. We thank K. Burke and an anonymous reviewer for their pertinent and useful comments, and Guest Editor Y. Gunnell for improving the English.

\section{References}

Bamford, M.K., 2000. Cenozoic macro-plants. In: Partridge, T.C., Maud, R.R. (Eds.), The Cenozoic of southern Africa. Oxford University Press, Oxford, pp. 351-356.

Bamford, M.K., de Wit, M.C.J., 1993. Taxonomic description of fossil wood from Cainozoic Sak River terraces, near Brandvlei, Bushmanland, South Africa. Palaeontologia Africana 30, 71-80.

Bardossy, G., Aleva, G.J.J., 1990. Lateritic bauxites. Elsevier, Amsterdam.

Beauvais, A., Chardon, D., 2013. Modes, tempo, and spatial variability of Cenozoic cratonic denudation: the West African example. Geochemistry, Geophysics, Geosystems 14, 1590-1608.

Beauvais, A., Ruffet, G., Hénocque, O., Colin, F., 2008. Chemical and physical erosion rhythms of the West African Cenozoic morphogenesis: The ${ }^{39} \mathrm{Ar}-{ }^{40} \mathrm{Ar}$ dating of supergene K-Mn oxides. Journal of Geophysical Research 113 (F4), doi:10.1029/2008JF000996. 
Botha, G.A., 2000. Paleosols and duricrusts. In: Partridge, T.C., Maud, R.R. (Eds.), The Cenozoic of southern Africa. Oxford University Press, Oxford, pp. 131-144.

Braun, J., 2010. The many surface expressions of mantle dynamics. Nature Geoscience 3, 825-833.

Bremer, H., 1993. Etchplanation, review and comments of Büdel's model. Zeitschrift für Geomorphologie, Supplement Band 92, 189-200.

Brown, R.W., Gallagher, K., Gleadow, A.J.W., Summerfield, M.A., 2000. Morphotectonic evolution of the South Atlantic margins of Africa and South America. In: Summerfield, M.A. (Ed.), Geomorphology and global tectonics. Wiley, Chichester, pp. 255-281.

Brown, R.W., Summerfield, M.A., Gleadow, A.J.W., 2002. Denudation history along a transect across the Drakensberg Escarpment of southern Africa derived from apatite fission track thermochronology. Journal of Geophysical Research 107, B12, 2333, doi:2310.1029/2001JB000745.

Büdel, J., 1957. Die "Doppelten Einebnungsflächen" in der feuchten Tropen. Zeitschrift für Geomorphologie 1, 201-228.

Büdel, J., 1982. Climatic Geomorphology. Princeton University Press, Princeton, New Jersey, $443 \mathrm{pp}$.

Burke, K., Gunnell, Y., 2008. The African erosion surface: a continental-scale synthesis of geomorphology, tectonics, and environmental change over the past 180 million years. Geological Society of America Memoir 201, 66 pp.

Chardon, D., Chevillotte, V., Beauvais, A., Grandin, G., Boulangé, B., 2006. Planation, bauxites and epeirogeny: One or two paleosurfaces on the West African margin? Geomorphology 82, 273-282.

Cornell, D.H., Thomas, R.J., Gibson,R., Moen, H.F.G., Moore, J.M., Reid, D.L., 2006. The Namaqua-Natal Province. In: Johnson, M.R., Anhaeuseer, C.R., Thomas, R.J. (Eds.), The geology of South Africa. Geological Society of South Africa and Council for Geosciences, Johannesburg and Pretoria, pp. 325-379.

Dauteuil, O., Rouby, D., Braun, J., Guillocheau, F. Deschamps, F. 2013. Post-Breakup evolution of the margin of Namibia: constraints from a numerical approach. Tectonophysics 604, 122-138.

Davis, W.M., 1899. The geographical cycle. Geographical Journal 14, 481-504.

Davis, W.M., 1930. Rock floors in arid and humid climates. Journal of Geology 38, 1-27. 
Davis, W.M., 1938. Sheetfloods and streamfloods. Geological Society of America Bulletin 49, 1337-1416.

De Villiers, S.E., 1999. Palaeobotanical implications arising from palynological studies of Eocene sediments from the continental shelf, Northern Cape Province, South Africa, Actes du 4ème Symposium de Palynologie africaine. Geo-Eco-Trop, Numéro Spécial, Sousse, Tunisie, pp. 129-140.

De Wit, M.C.J., 1999. Post-Gondwana drainage and the development of diamond placers in western South Africa. Economic Geology 94, 721-740.

De Wit, M.C.J., Bamford, M.K., 1993. Fossil wood from the Brandvlei area, Bushmanland, as an indication of palaeoenvironmental changes during the Cainozoic. Palaeontologia Africana 30, 81-89.

Decker, J.E., Niedermann, S., de Wit, M.J., 2013. Climatically influenced denudation rates of the southern African plateau: clues to solving a geomorphic paradox. Geomorphology 90, 48-60.

Dohrenwend, J.C., Parsons, A.J., 2009. Pediments in arid environments. In: Parsons, A.J., Abrahams, A.D. (Eds.), Geomorphology of desert environments. Springer, BerlinHeidelberg, pp. 377-411.

Dresch, J., 1947. Pénéplaines africaines. Annales de Géographie 302, 125-137.

Du Plessis, P.I., 1993. The sedimentology of the Kalahari Group in four study areas in northern Botswana. PhD thesis (unpublished), University of Stellenbosch South Africa.

Gallagher, K., Brown, R., 1999a. The Mesozoic denudation history of the Atlantic margins of southern Africa and southeast Brazil and the relationship to offshore sedimentation. In: Cameron, N.R., Bate, R.H., Clure, V.S. (Eds.), The oil and gas habitats of South Atlantic. Geological Society of London, Special Publication 153, pp. 41-53.

Gallagher, K., Brown, R., 1999b. Denudation and uplift at passive margins: the record on the Atlantic Margin of southern Africa. Philosophical Transactions of the Royal Society London 357, 835-859.

Gomez, B., Martinez-Delclos, X., Bamford, M., Philippe, M., 2002. Taphonomy and palaeoecology of plant remains from the oldest African Early Cretaceous amber locality. Lethaia 35, 300-308.

Grandin, G., Thiry, M., 1983. Les grandes surfaces continentales tertiaires des régions 
chaudes. Succession des types d'altération. Cahiers de l'Office de la Recherche Scientifique et Technique Outre-Mer, série Géologie XIII, pp. 3-18.

Gresse, P.G., von Veh, M.W., Frimmel, H.E., 2006. Namibian (Neoproterozoic) to Early Cambrian successions. In: Johnson, M.R., Anhaeuser, C.R., Thomas, R.J. (Eds.), The geology of South Africa. Geological Society of South Africa and Council for Geosciences, Johannesburg, Pretoria, pp. 395-420.

Guillocheau, F., Rouby, D., Robin, C., Helm, C., 2012. Quantification and causes of the terrigeneous sediment budget at the scale of a continental margin: a new method applied to the Namibia-South Africa margin. Basin Research 24, 3-30.

Gutzmer, J., Du Plooy, A.P., Beukes, N.J., 2012. Timing of supergene enrichment of lowgrade sedimentary manganese ores in the Kalahari Manganese Field, South Africa. Ore Geology Reviews 47, 136-153.

Haq, B.U., Hardenbol, J., Vail, P.R., 1987. Chronology of fluctuating sea levels since the Triassic. Science 235, 1156-1167.

Heckroodt, R.O., 1992. Kaolin ressources of the Republic of South Africa. Handbook of the Geological Survey, Republic of South Africa 13, 102.

Holmes, C.D., 1955. Geomorphic development in humid and arid regions: a synthesis. American Journal of Science 253, 377-390.

Jacob, R.J., Bluck, B.J., Ward, J.D., 1999. Tertiary-age diamondiferous fluvial deposits of the lower Orange River valley, southwestern Africa. Economic Geology 94, 749758.

Johnson, M.R. van Vuuren, C.J., Visser, J.N.J., Cole, D.I., Wickens, H. de V., Christie, A.D.M., Roberts, D.L., Brandl, G., 2006. Sedimentary rocks of the Karoo Supergroup. In: Johnson, M.R., Anhaeuser, C.R., Thomas, R.J. (Eds.), The geology of South Africa. Geological Society of South Africa and Council for Geosciences, Johannesburg, Pretoria, pp. 461-499.

Jourdan, F., Féraud, G., Bertrand, H., Watkeys, M.K., Renne, P.R., 2008. The ${ }^{40} \mathrm{Ar} /{ }^{39} \mathrm{Ar}$ ages of the sill complex of the Karoo large igneous province: Implications for the Pliensbachian-Toarcian climate change. Geochemistry, Geophysics, Geosystems, 9, Q06009.

King, L.C., 1951. South African scenery; a textbook of geomorphology, (2nd edition). Oliver and Boyd, Edinburgh, 379 pp.

King, L.C., 1953. Canons of landscape evolution. Geological Society of America Bulletin 
64, 721-751.

King, L.C., 1955. Pediplanation and isostasy, an example from South Africa. Proceedings of the Geological Society of London 1527, 115-118.

King, L.C., 1956. Drakensberg Scarp of South Africa: a clarification. Geological Society of America Bulletin 67, 121-122.

King, L.C., 1962. Morphology of the Earth: a study and synthesis of world scenery. Oliver and Boyd, Edinburgh, 726 pp.

King, L.C., 1963. South African scenery, a textbook of geomorphology (3rd edition). Oliver and Boyd, Edinburgh, 308 pp.

Kounov, A., Viola, G., de Wit, M.J., Andreoli, M., 2009. Denudation along the Atlantic passive margin: new insights from apatite fission-track analysis on the western coast of South Africa. In: Lisker, F., Ventura, B., Glasmacher, U. (Eds.), Geological Society of London, Special Publication 324, pp. 287-306.

Mabbutt, J.A., 1955. Pediment land forms in Little Namaqualand, South Africa. Geographical Journal 121, 77-83.

Mabbutt, J.A., 1961. "Basal surface" or "weathering front". Proceedings of the Geologists' Association 72, 357-358.

Mabbutt, J.A., 1966. Mantle-controlled planation of pediments. American Journal of Science 264, 78-91.

Mammerickx, J., 1964. Pédiments désertiques et pédiments tropicaux. Acta Geographica Lovaniensia 3, 359-370.

Matmon, A., Mushkin, A., Enzel, Y., Grodek, T., Ream, A., 2013. Erosion of a granite inselberg, Gross Spitzkoppe, Namib Desert. Geomorphology 201, 52-59.

McFarlane, M.J., Eckardt, F.D., Coetzee, S.H., Ringrose, S., 2010. An African surface weathering profile in the Kalahari of North West Ngamiland, Botswana: processes and products. Zeitschrift für Geomorphologie 54, 273-303.

McGregor, D., 2009. AAPG ICE Rio de Janeiro "South Atlantic Deepwater Reservoirs: Responses to Tectonic, Climatic and Eustatic Controls from Two Not-So-Passive Margins," Search and Discovery Article \#90100.

Migon, P., 2004a. Planation surfaces. In: Goudie, A.S. (Ed.), Encyclopedia of Geomorphology. Routledge, London, pp. 788-792.

Migon, P., 2004b. Peneplain. In: Goudie, A.S. (Ed.), Encyclopedia of Geomorphology. Routledge, London, pp. 771-772. 
Migon, P., 2004c. Etching, etchplain and etchplanation. In: Goudie, A.S. (Ed.), Encyclopedia of Geomorphology. Routledge, London, pp. 345-347.

Migon, P., 2006. Granite landscapes of the world. Oxford University Press, Oxford, 384 pp.

Miller, K.G. ,Kominz, M.A., Browning, J.V., Wright, J.D., Mountain, G.S., Katz, M.E., Sugerman, P.J., Cramer, B.S., Christie-Blick, N., Pekar, S.F., 2005. The Phanerozoic record of global sea-level change. Science 310, 1293-1298.

Millot, G., 1980. Les grands aplanissements des socles continentaux dans les pays subtropicaux, tropicaux et désertiques, Livre Jubilaire Société Géologique de France, Mémoire hors-série, pp. 295-305.

Millot, G., 1981. Weathering sequences. "Climatic" planations. Leveled surfaces and paleosurfaces. In: van Olphen, H., Veniale, F. (Eds.), Proceedings of the VII International Clay Conference, Bologna and Pavia. Elsevier, Amsterdam, pp. 585593.

Moulin, M., Aslanian, D. Unternehr, P., 2010. A new starting point for the South and Equatorial Atlantic Ocean. Earth-Science Reviews 98, 1-37.

Mvondo, F., Dauteuil, O., Guillocheau, F. 2011. The Fish River Canyon (southern Namibia): A record of Cenozoic mantle dynamics? Comptes Rendus Géosciences $343,478-485$.

Ollier, C.D., 1959. A two-cycle theory of tropical pedology. Journal of Soil Science 10, 137-148.

Partridge, T.C., Maud, R.R., 1987. Geomorphic evolution of southern Africa since the Mesozoic. South African Journal of Geology 90, 179-208.

Phillips, J.D., 2002. Erosion, isostatic response, and the missing peneplains. Geomorphology 45, 225-241.

Pickford, M., Senut, B., 1999. Geology and palaeobiology of the Namib desert Southwest Africa. Geological Survey of Namibia, Memoir 18, 155 pp.

Pickford, M., Senut, B., 2003. Miocene palaeobiology of the Orange River Valley, Namibia. In: Pickford, M., Senut, B. (Eds.), Geology and Palaeobiology of the central and southern Namib., Vol 2: Palaeontology of the Orange River Valley, Namibia. Memoir of the Geological Survey of Namibia, pp. 1-22.

Pickford, M., Senut, B., Morales, J., Mein, P., Sanchez, I.M., 2008. Mammalia from the Lutetian of Namibia. Memoir of the Geological Survey of Namibia 20, 465-514. 
Raab, M.J., Brown, R.W., Gallagher, K., Carter, A., Weber, K., 2002. Late Cretaceous reactivation of major crustal shear zones in northern Namibia; constraints from apatite fission track analysis. Tectonophysics 349, 75-92.

Rowley, D.B., 2013. Sea level: Earth's dominant elevation-Implications for duration and magnitudes of sea level variations. Journal of Geology 121, 445-454.

Salomon, J.-N. 2007. Cônes d'éboulis, de déjection, glacis et piémonts: essai de définitions. Études de Géographie Physique 34, 53-67.

Sandersen, A., 2006. A palynological investigation of the offshore Cretaceous sequence on the south-west coast of South Africa. PhD Thesis Thesis, University of the Witwatersrand, Johannesburg, South Africa.

Selby, M.J., 1982. Form and origin of some bornhardts of the Namib Desert. Zeitschrift für Geomorphologie 26, 1-15.

Thomas, M.F., 1978. The study of inselbergs. Zeitschrift für Geomorphologie, Supplement Band 31, 1-41.

Thomas, M.F., 1989a. The role of etch processes in landform development. I. Etching concepts and their applications. Zeitschrift fur Geomorphologie 33, 129-142.

Thomas, M.F., 1989b. The role of etch processes in landform development. II. Etching and the formation of relief. Zeitschrift fur Geomorphologie 33, 257-274.

Tinker, J., de Wit, M., Brown, R., 2008a. Linking source and sink: Evaluating the balance between onshore erosion and offshore sediment accumulation since Gondwana break-up, South Africa. Tectonophysics 455, 94-103.

Tinker, J., de Wit, M., Brown, R., 2008b. Mesozoic exhumation of the southern Cape, South Africa, quantified using apatite fission track thermochronology. Tectonophysics 455, 77-93.

Twidale, C.R., 1981. Early explanations of inselbergs. Revue de Géomorphologie dynamique 30, 49-61.

Twidale, C.R., 1983a. Pediments, peneplains and ultiplains. Revue de Géomorphologie dynamique $32,1-35$.

Twidale, C.R., 1983b. Australian laterites and silcretes: ages and significance. Revue de Géologie dynamique et de Géographie physique 24, 35-45.

Twidale, C.R., Bourne, J.A., 2013. Pediments as etch forms: implications for landscape evolution. Journal of Geology 121, 607-622.

Van Wyk, J.P., Pienaar, L.F., 1986. Diamondiferous gravels of the lower Orange River, 
Namaqualand. In: Anhaeusseer C.R. (Ed.), Mineral Deposits of South Africa, Geological Society of South Africa, Johannesburg, pp. 2309-2321.

Wayland, E.J., 1933. Peneplains and some other erosional platforms. Note 1. Annual Report Bulletin, Protectorate of Uganda, Geological Survey, Department of Mines, pp. 77-79.

Whitaker, C.R., 1979. The use of the term "pediment" and related terminology. Zeitschrift für Geomorphologie 23, 427-439.

White, K., 2004. Pediment. In: Goudie, A.S. (Ed.), Encyclopedia of Geomorphology. Routledge, London, pp. 768-771.

Wirthmann, A., 1999. Geomorphology of the Tropics. Springer, Heidelberg, 323 pp.

\section{Figure Captions}

Fig. 1. Morphology of the study area. The Orange valley is located in the south of the southern African Plateau (insert). The river flows from the inner part of the Plateau to the Atlantic Ocean, and cuts a gorge through the SW-African marginal bulge. Note the location of a tilted coastal domain that is slightly more incised than the topography inland.

Fig. 2. A working classification of erosion surfaces. Four types of erosion surface were distinguished depending on whether they are predominantly formed by erosion or by weathering, i.e. whether climate or crustal deformation are the main forcing factors. These definitions are tied to the geomorphic context of the study area. The initial topography is shown in light grey, bedrock in dark grey.

Fig. 3. Erosion surfaces in the study area. Three surfaces were identified: two pediplains and an etchplain. Pediplain 1 and the etchplain were degraded by inroads made by pediplain 2. The remnant geomorphic features indicate that these two late surfaces covered the entire study area and were driven by a local base level corresponding to a proto-Orange Valley. White dots locate the Orange alluvial terraces of Burdigalian age (Pickford and Senut, 1999; Pickford and Senut, 2003). 
Fig. 4. 2.5D perspective of the north side of the Orange River displaying the shapes and links between the erosion surfaces. a: view of pediplain 1 with inselbergs north of Karasburg; b: view of the different erosion surfaces in the Noordoerwer area; c: $2.5 \mathrm{D}$ view of the topography of the study area; $d$ : synthetic topographic section of the three surfaces.

Fig. 5. The Gamkab River valley: case study of a pedivalley. a: parallel drainage pattern on the north flank of the valley (Google Earth image); b: landscape with the Gamkab River underlined by trees; c: topographic profile down the flank of the pedivalley; d: mesh block diagram of the Gamkab catchment showing how pediplain 2 has encroached on pediplain 1. Also note the striking change in drainage pattern between the two pediplains.

Fig. 6. Drainage pattern and erosion surfaces. The drainage pattern (black lines) was automatically extracted from the DEM. The two pediplains (yellow and orange) display different drainage networks: parallel for pediplain 1 and dendritic for pediplain 2. The current Orange River is shown in dark brown. The grey background displays the topography and the thick dotted line indicates the limit of the east- and west-flowing drainages.

Fig. 7. Set of longitudinal river profiles in the study area. All profiles were normalised both in length and height (insert in lower left corner). Blue corresponds to a concave, red to a convex, and green to a linear profile. The insert in the upper right corner displays the longitudinal profile of the Orange River, with its main knickpoint at the Augrabies Falls. Note the difference in river profiles between the coastal and inner domains.

Fig. 8. Erosion surfaces and lithology. Each surface is represented with its corresponding bedrock outcrops. The lithological nomenclature was obtained from the geological maps provided by the South African Geological Survey. Each map corresponds to only one planation surface or its corresponding degraded avatar, and the zone without colour to the other planation surfaces. Pediplains 1 and 2 do not display any correlation with lithology. The etchplain shows one dominant colour, which 
corresponds mainly to sedimentary rocks and locally to the volcanics. However, similar outcrops are also present on other surfaces, indicating that lithological control is limited. We conclude that lithology had no influence on topographic growth other than perhaps on a very local scale.

Fig. 9. Landscape evolution of the Orange River valley area. We correlated landscape evolution (second column) around the Orange River valley with the climatic environment (third column) and with variations in base level (fourth column). After a long period of weathering from the late Paleocene to the middle Eocene, landscape change was initially driven by a change in climatic conditions. A crustal deformation event occurred subsequently during the early Miocene, changing the drainage polarity and generating pediplain 2. A rise in sea level during the Burdigalian, and finally a fall in sea level shaped the present-day landscape. Variations in base level are shown on a logarithmic scale. 


\section{ACCEPTED MANUSCRIPT}

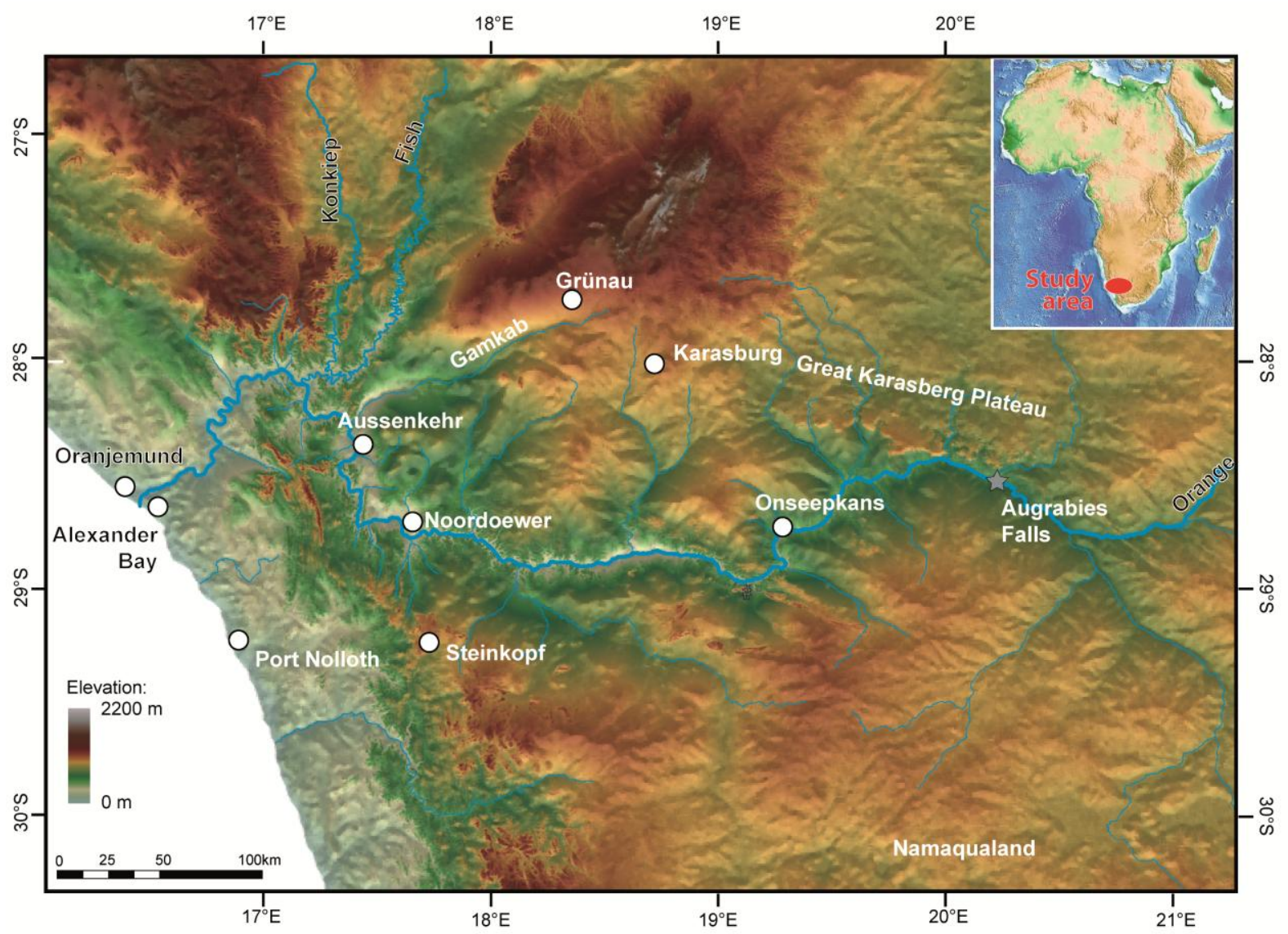

figure 1

Figure 1 


\section{Peneplain}
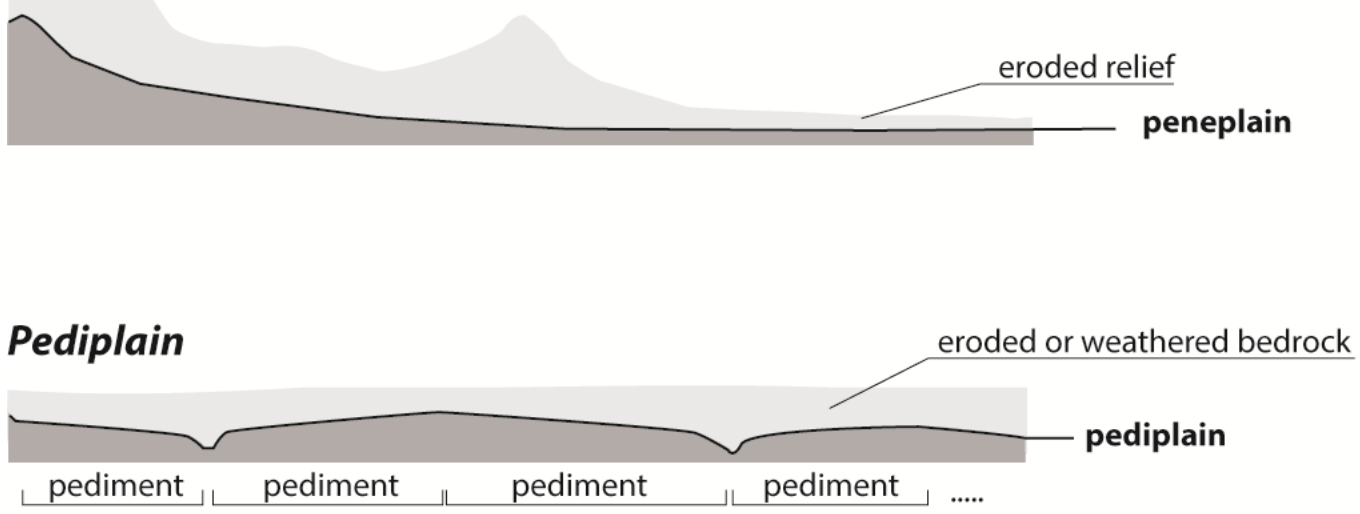

Weathering surfaces or mantled etchplain
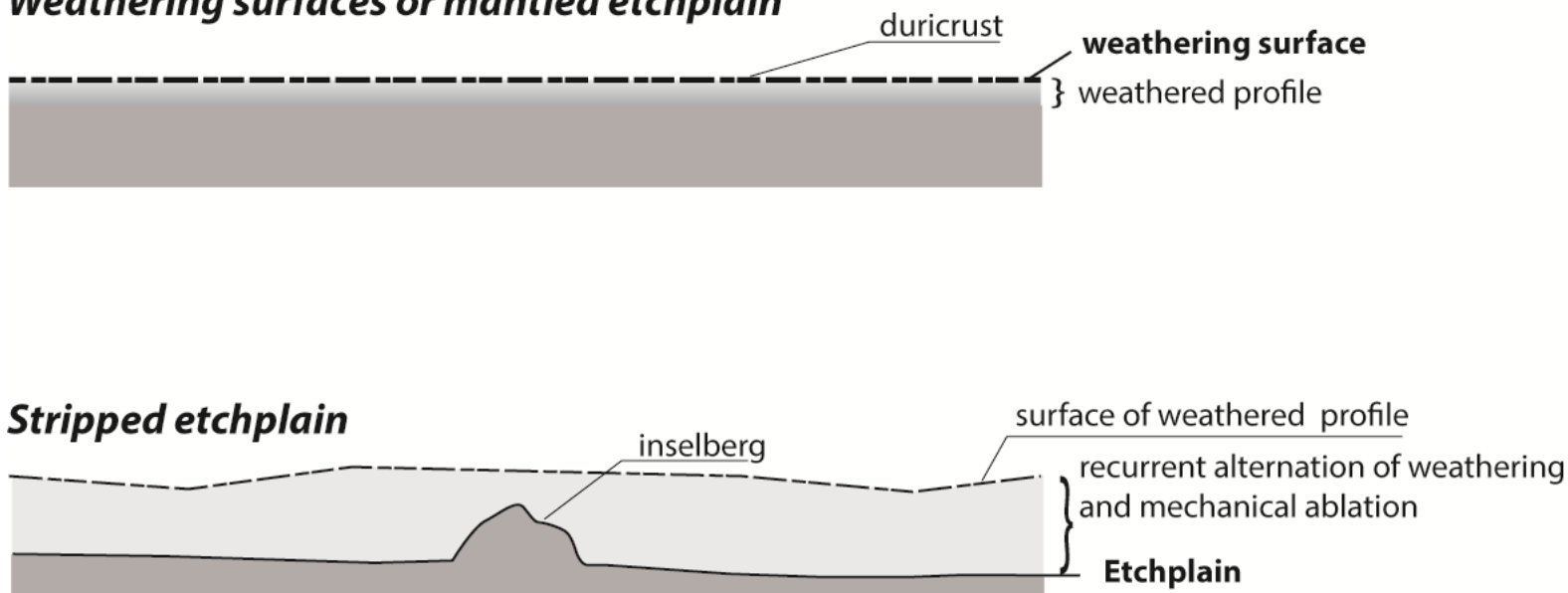

figure 2

\section{Figure 2}




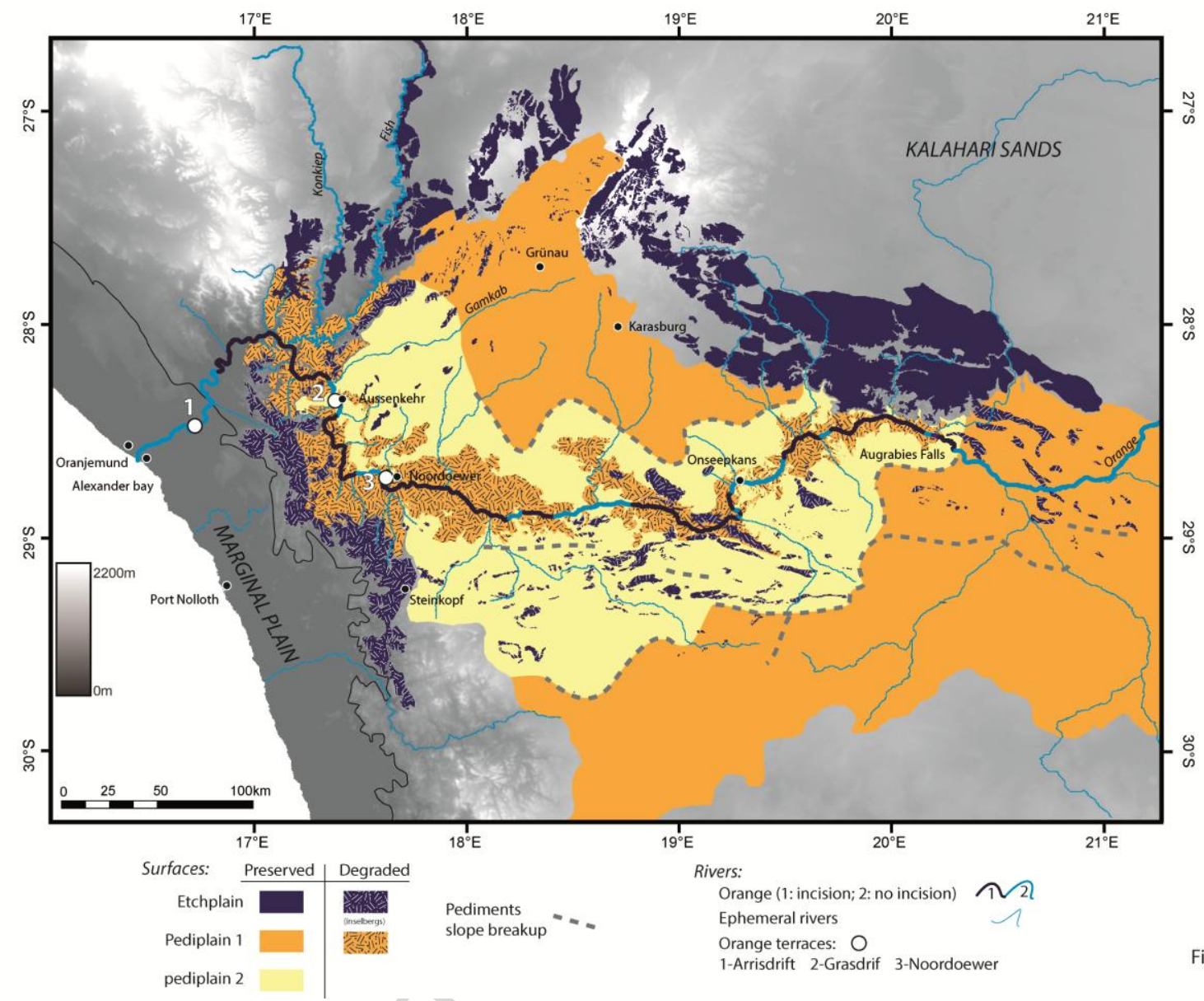

Figure 3 

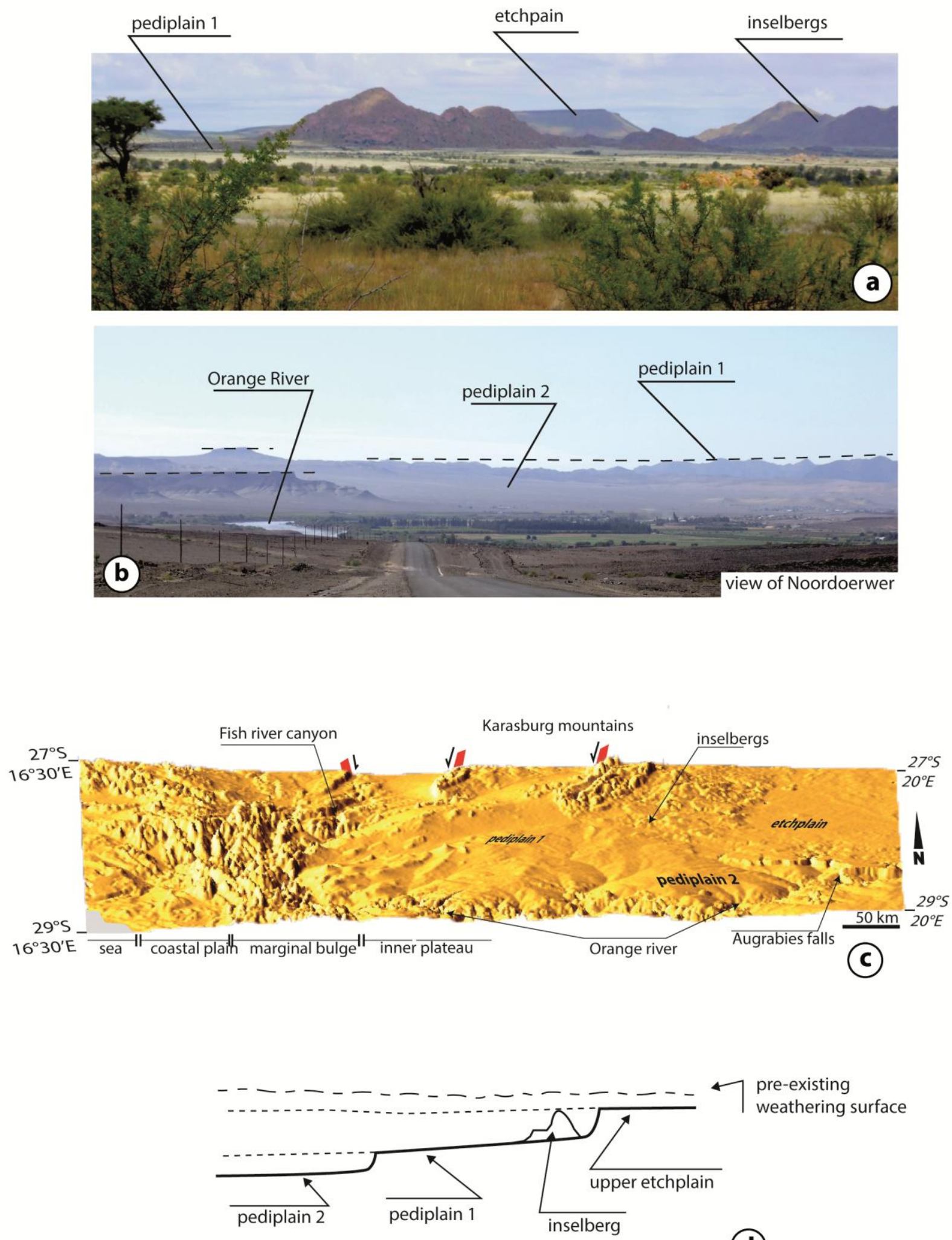

(d)

\section{Figure 4}



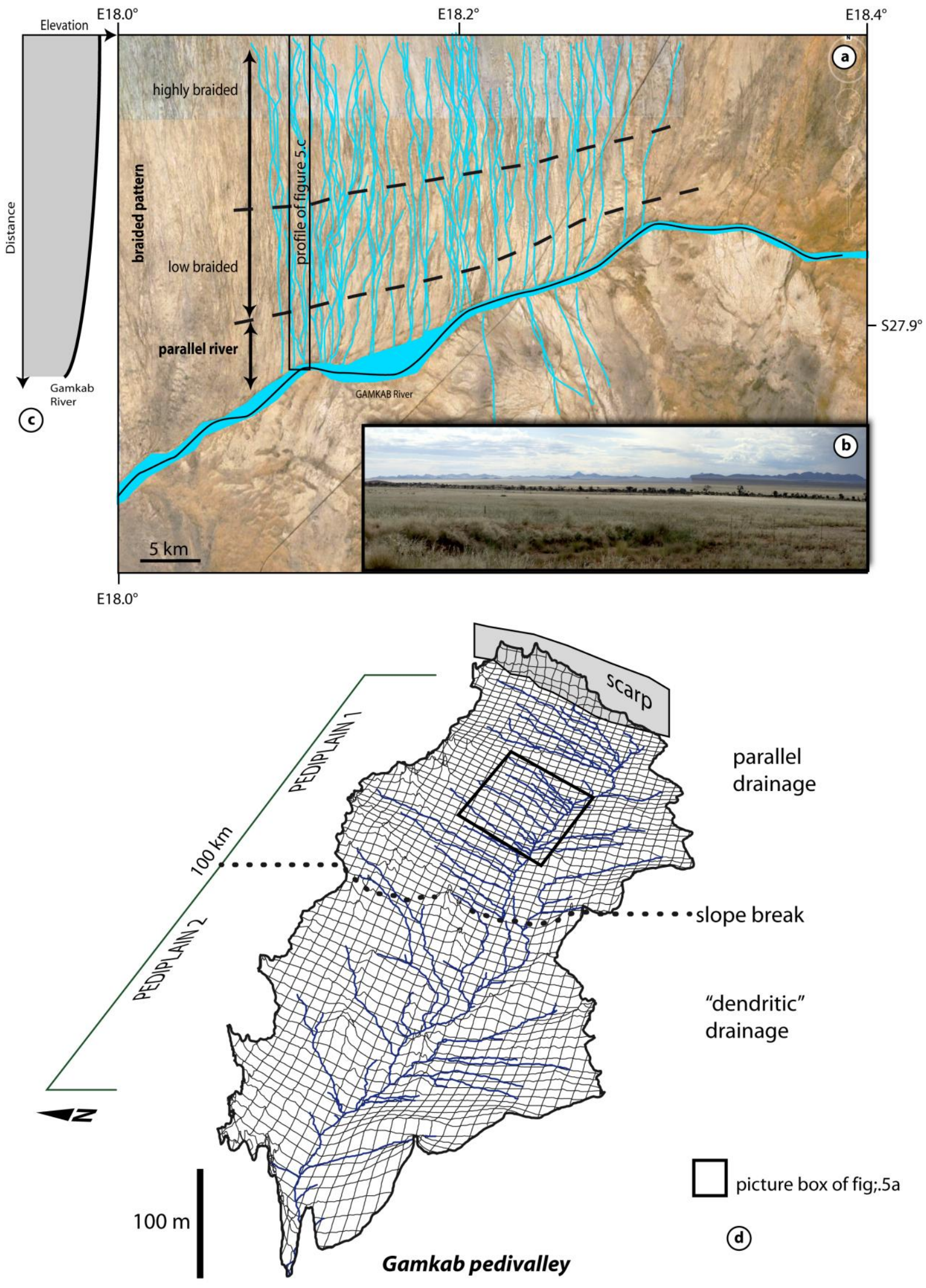

Figure 5

Figure 5 


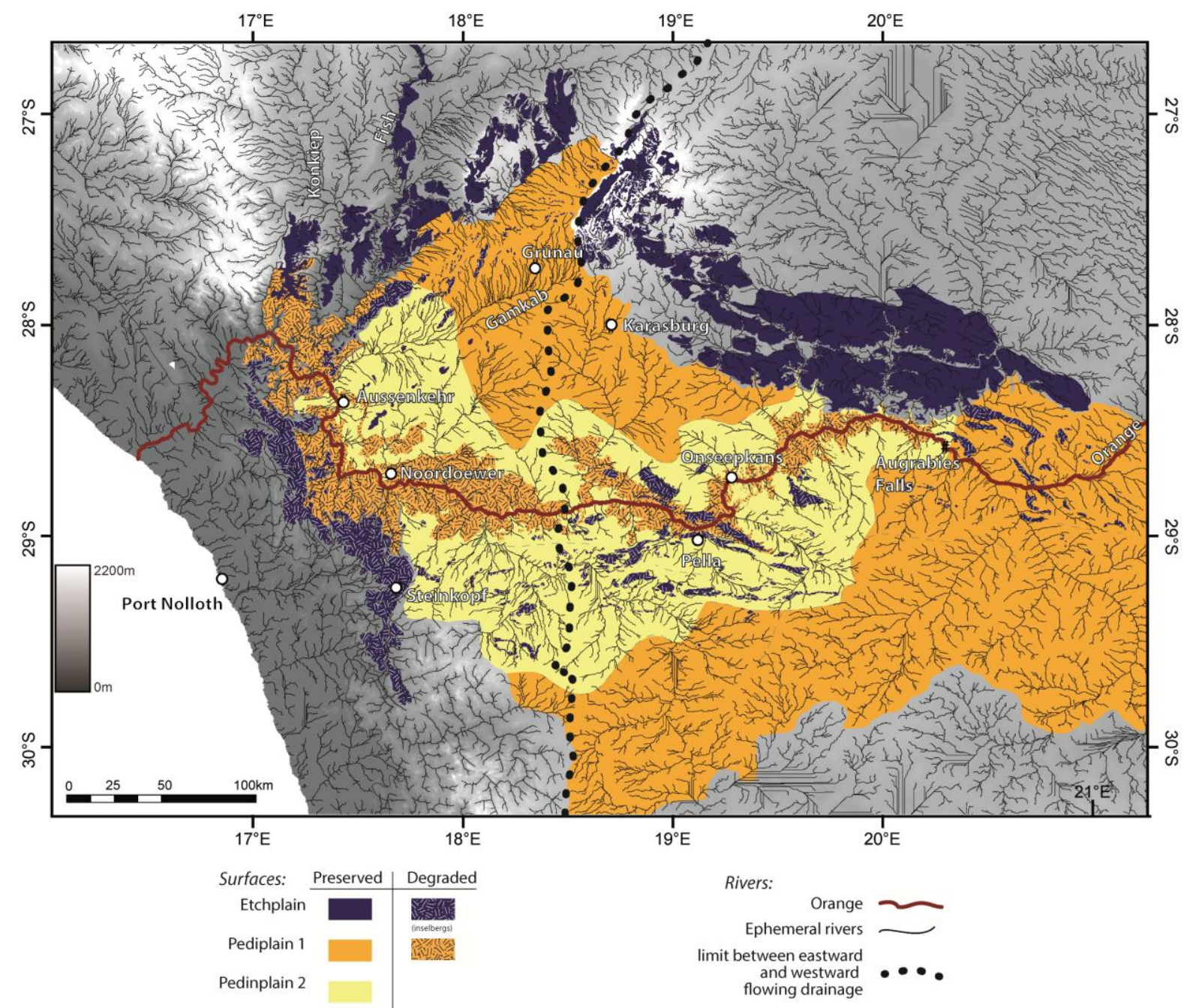

Figure 6 


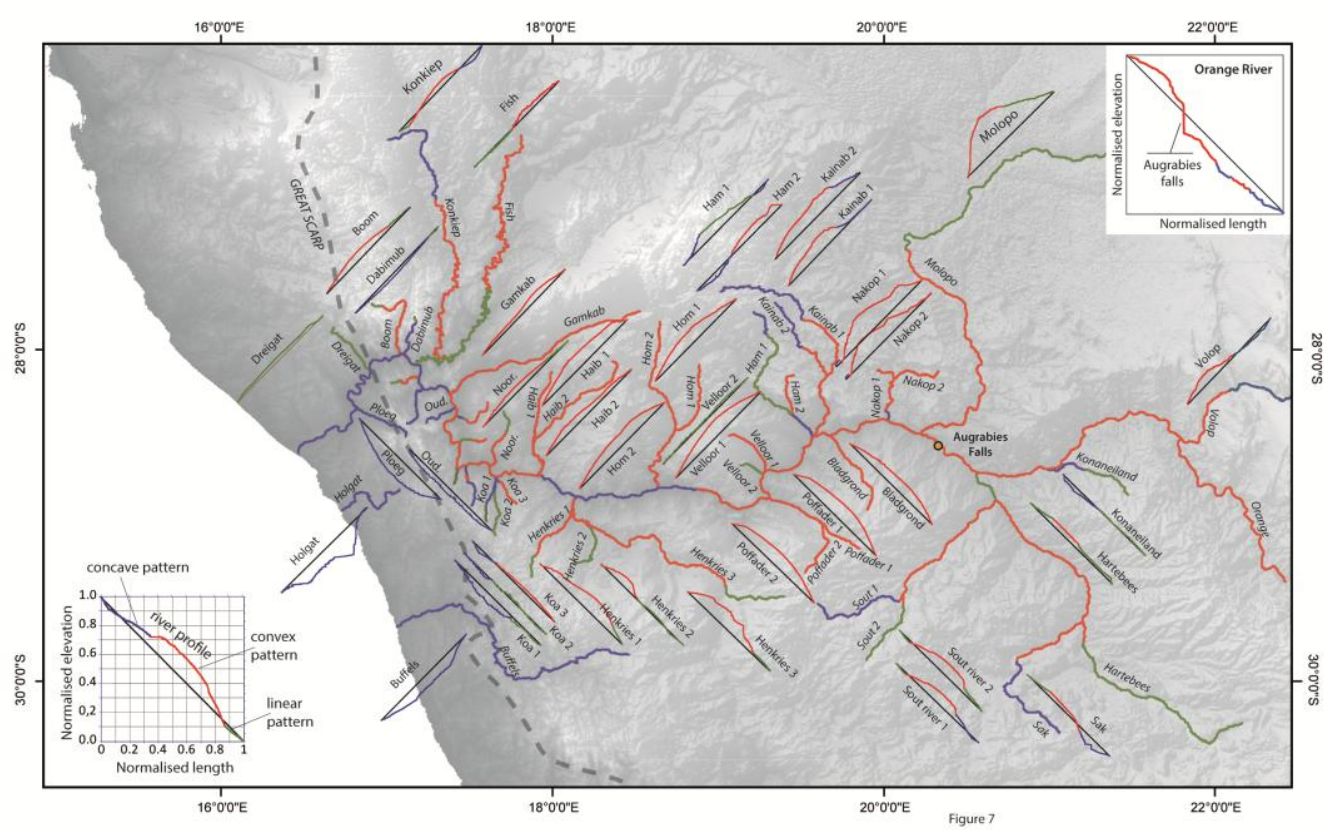

Figure 7 

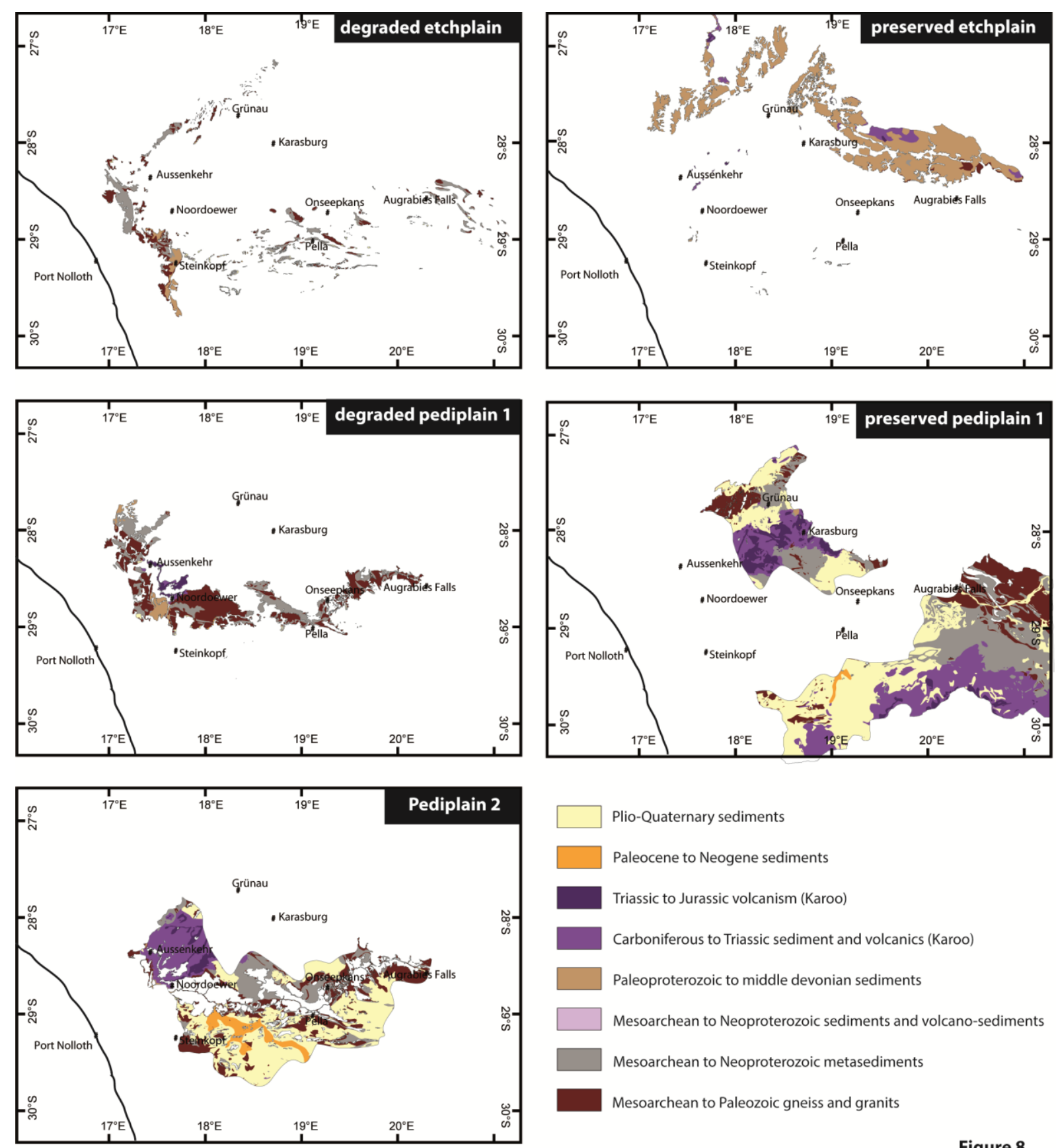

Plio-Quaternary sediments

Paleocene to Neogene sediments

Triassic to Jurassic volcanism (Karoo)

Carboniferous to Triassic sediment and volcanics (Karoo)

Paleoproterozoic to middle devonian sediments

Mesoarchean to Neoproterozoic sediments and volcano-sediments

Mesoarchean to Neoproterozoic metasediments

Mesoarchean to Paleozoic gneiss and granits

Figure 8

Figure 8 


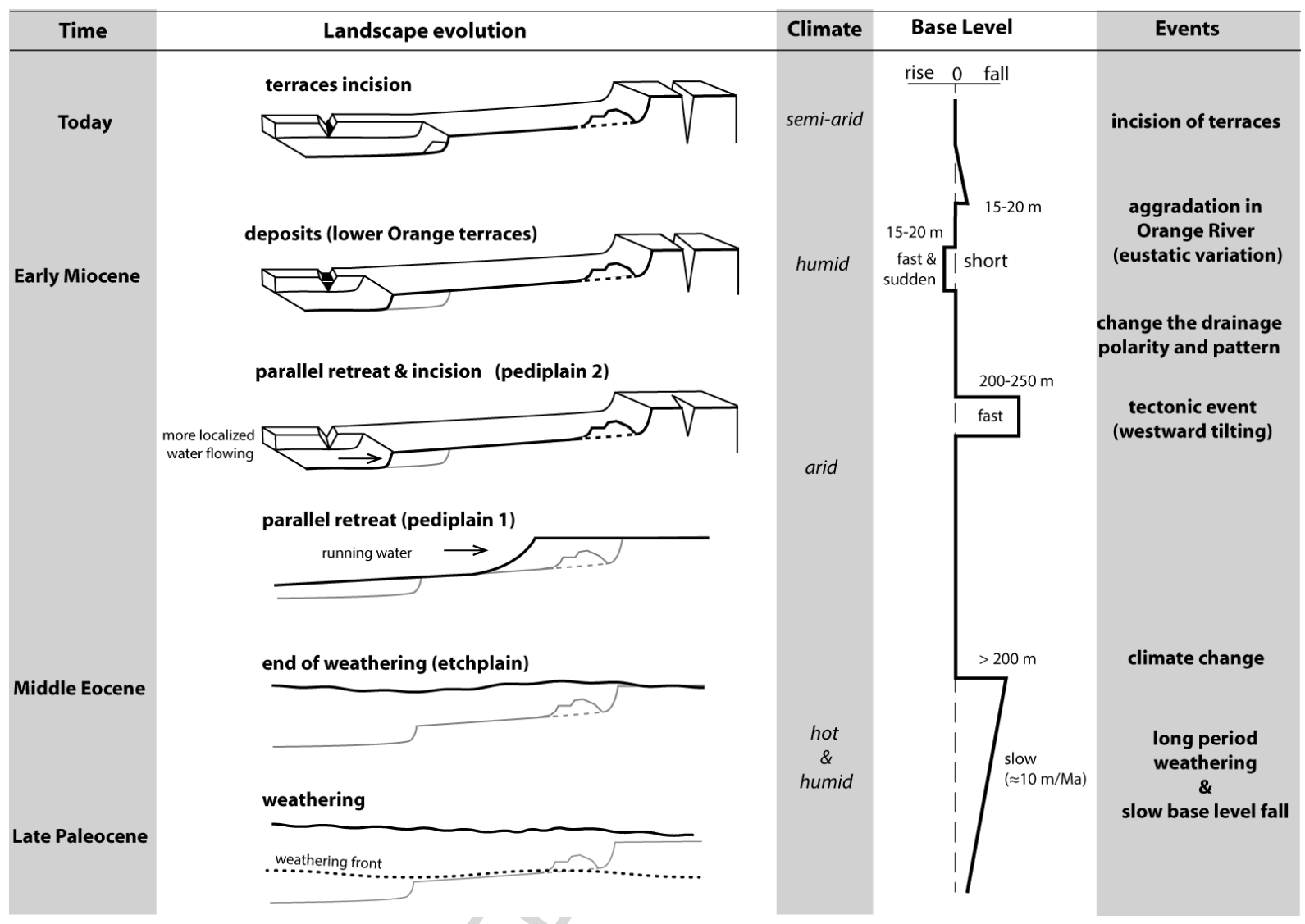

\section{Figure 9}




\section{Highlights}

We mapped three planation surfaces in Orange valley: an etchplain and two pediplains.

We simplified the typology of planation surfaces from genetic processes.

We defined a new landform type: the pedivalley.

We estimated vertical displacements from geomorphic markers: at least $400 \mathrm{~m}$ since late Paleocene. 